\title{
Lateral Supraorbital Approach Versus Classic Pterional Approach In Suprasellar Meningiomas Regarding Accessibility and Safety
}

\author{
AHMED A. ABD EL-KHALEK, M.D.* and MOHAMED SHABAN, M.D.** \\ The Department of Neurosurgery, Faculties of Medicine, Cairo* and Beni-Suif** Universities
}

\begin{abstract}
Background: Minimally invasive Lateral Supraorbital Approach (LSO) is a modified classic pterional approach with advantages of a shorter skin incision and small craniotomy as compared with the pterional approach.
\end{abstract}

Aim of Study: To present our surgical experience in distinguishing between Lateral Supraorbital Approach [LSO] and conventional pterional approach regarding accessibility and safety in suprasellar meningioma.

Patients and Methods: This is a retrospective study of 19 cases who were diagnosed with suprasellarmeningiomas and were operated between March 2011 to March 2015 in Cairo University Hospital, and Beni-Sueif University Hospital. The patient was divided into two groups, group A (8 cases) operated via LSO, and group B (11 cases) managed via conventional pterional approach with follow-up period for one year the follow-up images were done immediately post-operative then every six months till 12 months.

Results: Complete resection was obtained in 7 cases $(75 \%)$ in group A, while it was in 8 cases $(72.6 \%)$ within group B, visual acuity improvement in group A was in 4 cases $(50 \%)$, in group B it was in 6 cases (54\%).

Vision unchanged in 3 cases (3 7.5\%) group A, and in 4 cases (365\%) group B.

Vision deteriorated in one case $(12,5 \%)$ in group $\mathrm{A}$, and in 1 case $(9.5 \%)$ group B.

Transient diabetes insipidus was in only one case (9.5\%) group B and no cases in group A.

Conclusion: LSO approach is safe, less invasive and provides same accessibility to suprasellarmeningiomas as compared to classic pterional approach.

Key Words: Lateral supraorbital - Pterional - Suprasellarmeningiomas.

Correspondence to: Dr. Ahmed A. Abd El-Khalek, The Department of Neurosurgery, Faculty of Medicine, Cairo University

\section{Introduction}

ALTHOUGH the pterional craniotomy approach is standard as a classic approach to reach the sellar, parasellar, and retrosellar regions, this technique requires extensive manipulations, disinsertion and possible injury of the temporalis muscle. Which leads to significant atrophy of the flesh also may lead to lead to damage of the frontal branch of cranial nerve VII, the facial nerve, many surgical modifications have been advised to reduce this problem [1-3].

The lateral-supraorbital-approach is alternative approach to the classic perional approach to operating on intracranial lesions located in the sellar and suprasellararea [4-6].

This approach has the advantages of having a shorter skin incision that doesn't extend to the front of the ear like the standard pterional approach thus doesn't affect the blood or nerve supply of the temporalis muscle. Additionally, there is no danger of damage to the frontal branch of the facial nerve because of the utilization of a myocutaneous flap protects it. This incision also has an excellent cosmetic result because it is usually hidden under the eyebrow hair line $[7,8]$.

A pterional approach has some problems related to the approach itself, such as wound tenderness, scalp numbness, a skin incision that is disfiguring, loss of hair along the scar line, increased bony irregularities around the large bone flap, and limitation of mouth opening.

In contrast, LSO approach minimizes the surgical wound, yet it can also lead to some disfigurement of the facial wound, palsy of the frontalis muscle, and head numbness. But good cosmetic results following a LSO approach have been de- 
scribed; patient satisfaction has occurred in comparing to pterionalapproaches [9-11]

\section{So there are two major questions:}

1- The extent of technical limitation to achieve our surgical goal.

2- The extent of patient satisfaction concerning our the surgical approach also approach using a supraorbital mini-craniotomy with a diameter of 3 to $4 \mathrm{~cm}$ is undoubtedly limiting for maneuvering surgical instruments; however, proper indications, meticulous surgical techniques, and adequate surgical instruments can overcome such technical limitations.

In the literature, many professional efforts have already been made to improve temporal hollows anteriorly and reduce or reconstruct the bone loss from the craniotomy. However, a longer scalp incision associated with hair loss and disfigurement adjacent to the hairline. The LSO approach is essential in minimally invasive neurosurgery for two reasons [12-17]

The only bur hole in the lateral supraorbital approach is located just above the frontozygomatic suture deep to the linea temporalis, as described by Yasargil et al., this bur hole location is the same for the pterional approaches $[\mathbf{1 , 2 , 1 8 - 2 1 ]}$.

Second, the shape of the techniques. As with many neurosurgical approaches, the LSO concept has its limitations. Post-operative loss of supraorbital sensation is not a frequent occurrence, although this has been shown recover in most cases and can be avoided by not extending the incision medial to the supraorbital foramen by $0.5 \mathrm{~cm}[22,23]$

The frontal air sinus can be prominent and because of that, an epidural abscess or possibly meningitis can result post-operatively if there wasn't adequate repair of the opened frontal sinus. A limitation in surgical techniques is the major drawback of the LSO approach.

Al-Mefty described the supraorbital approach to lesions of the base of the skull. Although the supraorbital approach provides the same surgical exposure and specially microsurgical instruments can overcome limited surgical freedom, the choice to use this LSO approach should be weighed by the confidence of surgeons [1].

The location of suprasellarmeningiomas is challenging because of their nearness to vital neural and vascular structures in the anterior cranial fossa.
Suprasellarmeningiomas, which includes anterior clinoid process, planumsphenoidalis, olfactory groove and diaphragmasellaemeningiomas this study aimed to compare the result of both approaches, regarding safety, accessibility [16-18,20,21]

\section{Patients and Methods}

Retrospectively 19 cases of suprasellarmeningiomas were operated between March 2011 to March 2015 in Cairo University Hospital, and Beni-Sueif University Hospital, the patient, were divided into two groups, group A (8 cases) operated via LSO, and group B (11 cases) operated via classic pterional approach with follow-up period every immediately post-operative then every three months till 12 months.

All patient followed by, clinical outcomes were recorded: Patient age, sex, histopathological diagnosis, the location of pathology, and extent of tumor resection: Gross-total resection, subtotal resection and partial resection, the following cosmetic results were recorded in both groups:

Group (A) eyebrow alopecia, frontalis muscle palsy, supraorbital hypoesthesia, and significant forehead depression.

In group (B) atrophy of the temporalis muscle also led to dysfunction of the frontal branch of the facial nerve.

The following complications were recorded in both group: CSF leak, wound infection, visual impairment, anosmia, diabetes insipidus, and any other significant neurological complication or deficit.

\section{Surgical technique:}

LSO Approach the LSO approach is a minimally invasive modification of the pterional approach, being located more anterior and frontally with a bone flap of maximum size is around 3 to $4 \mathrm{~cm}$ in diameter. It considers being used for vascular and neoplastic lesions of the anterior skull base [1-3] .

Under general anesthesia, the patient's head is placed in a 3-point rigid Mayfield and gently extended, and rotated to the opposite side. A skin incision is made in the superior part of the eyebrow, starting at the supraorbital notch medially (to avoid supraorbital nerve damage) to the lateral point of the eyebrow as it is better cosmetically when the scar is not evident within the eyebrow without the loss of hair. 
The subgaleal layer is undermined, the skin is retracted superiorly with a fish hook, and a pericranial flap is reflected inferiorly [4-6].

Only the upper anterior part of the temporalis muscle is split and retracted downwards towards the zygoma? A burr hole is then placed just under the temporal line of the bone A craniotomy $3 \mathrm{X}$ $4 \mathrm{~cm}$ is fashioned, by a drill, and the basal part can be drilled before lifting $[\mathbf{7 , 8 ]}$.

The dura is then opened. The subfrontal pathway is dissected using microscopic for visualization. With dissection of arachnoid and gradually CSF aspiration, the frontal lobe falls away the lesion is identified and managed using the microsurgical techniques $[\mathbf{1}, \mathbf{8 , 9}]$.

\section{Results}

Age mean in our study at the time of surgery was 40 years (range $40-50$ years), 5 male patients $(26.3 \%)$ and 14 female patients $(73.7 \%)$.

Of these 19 patients, there were nine patients in group (A) 11 patients in group (B) there weren't any statistically-significant differences comparing the surgical groups based on age or sex.

\section{Exclusion criteria:}

1- No recurrent surgery.

2- No previous radiotherapy.

3- Large lesion with extensive retrosellar or parasellar extension.

All included patients complained of headaches (18 patients; $100 \%$ ), and 15 patient (78\%) complain from visual field deficits pre-operative MRI studies were performed on all patients the mean tumor volumes according to operative group were as follows: Group (A) $30 \mathrm{~cm}^{3}$ group (B) (eyebrow), $45 \mathrm{~cm}^{3}$ the optic nerve compression or encroachment in 15 cases $(78 \%)$.

Gross total excision was in 7 cases (75\%) group $\mathrm{A}$, while it was in 8 cases $(72.6 \%)$ group $\mathrm{B}$, improvement of visual acuity within group A was in 3 cases $(50 \%)$, within group B in 5 cases $(55 \%)$ vision unchanged in 2 cases (33\%) group $\mathrm{A}$, and in 3 cases $(33.3 \%)$ group $B$, vision deteriorated in one case $(16.5 \%)$ group $\mathrm{A}$, and in 1 case $(11.1 \%)$ group B.

Transient DI was in 1 case $(9.5 \%)$ group B and no circumstances in group A.
Table (1): Clinical characteristics of 19 patients undergoing suprasellar meningioma resection.

\begin{tabular}{llc}
\hline Clinical characteristics & LSO & Pterional \\
\hline Sex (male/female) & $3 / 6$ & $2 / 9$ \\
Age & $40 y s$ & $40 y s$ \\
Symptoms: & & \\
Asymptomatic/incidental & 0 & 0 \\
Seizures & 4 & 6 \\
Syncope & 0 & 1 \\
Headache & 9 & 11 \\
Visual field defect & 6 & 9 \\
Cognitive dysfunction & 0 & 1 \\
\hline
\end{tabular}

Table (2): Clinical outcomes following resection of suprasellar meningioma.

\begin{tabular}{lll}
\hline Clinical improvement & LSO & Pterional \\
\hline - Headache & 7 & 7 \\
- Seizures counterol & 3 & 3 \\
- Visual field defect: & & \\
$\quad$ 1- Improvement & $3(50 \%)$ & $5(55 \%)$ \\
2- Deteroated & $1(16.5 \%)$ & $1(11.1 \%)$ \\
3- The same & $2(33 \%)$ & $3(33.3 \%)$ \\
- Temporalis muscle atrophy & 0 & 6 \\
- Frontal branch of facial nerve & 0 & 7 \\
affection & & \\
- Cosmetic result & Good & Fair \\
- Transient diabetes insipidus was & 0 & 1 \\
- Total resection & $7(75 \%)$ & $8(72.6 \%)$ \\
- Sub total resection & 2 & 3 \\
\hline
\end{tabular}

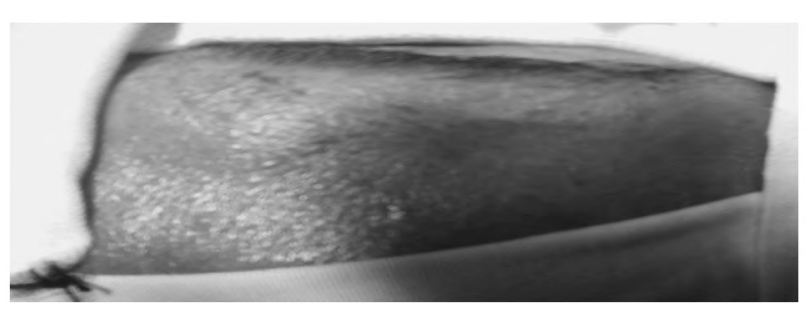

Image (1): Eyebrow in where skin incision was done.

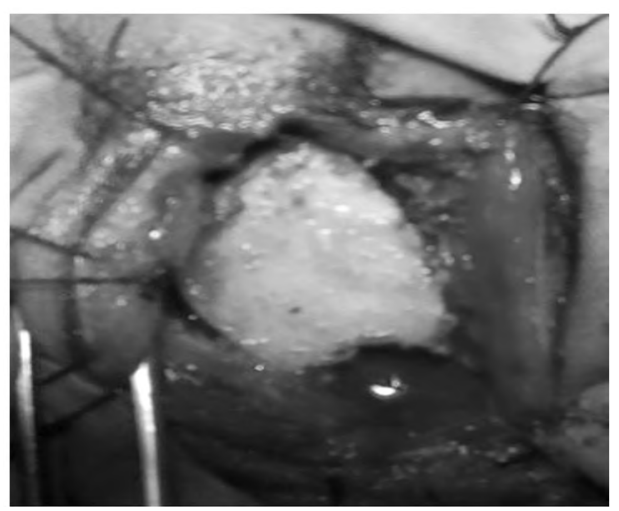

Image (2): The site of small supraorbital craniotomy. 


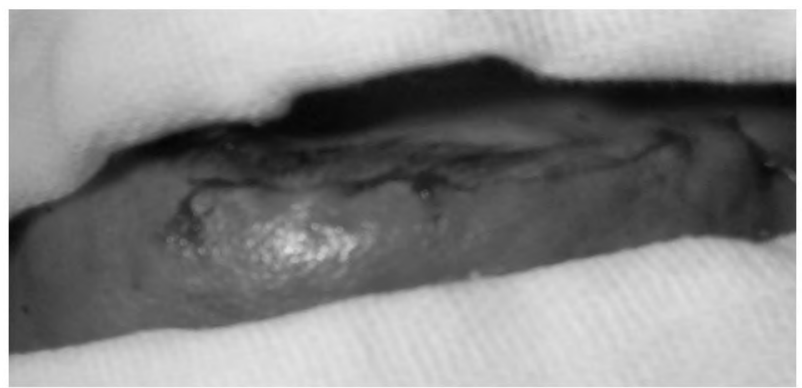

Image (3): Cosmetic skin suture

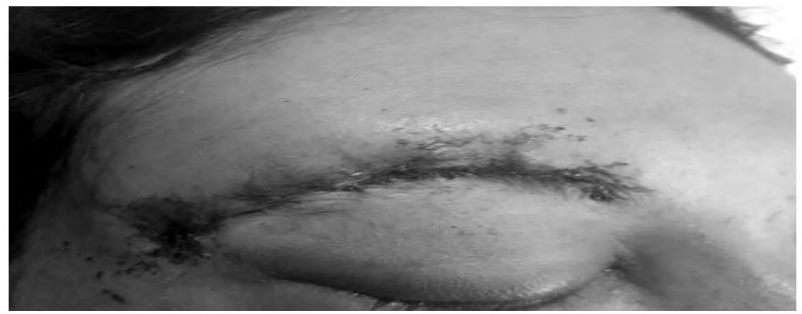

Image (4): Cosmetic result after 7 days.

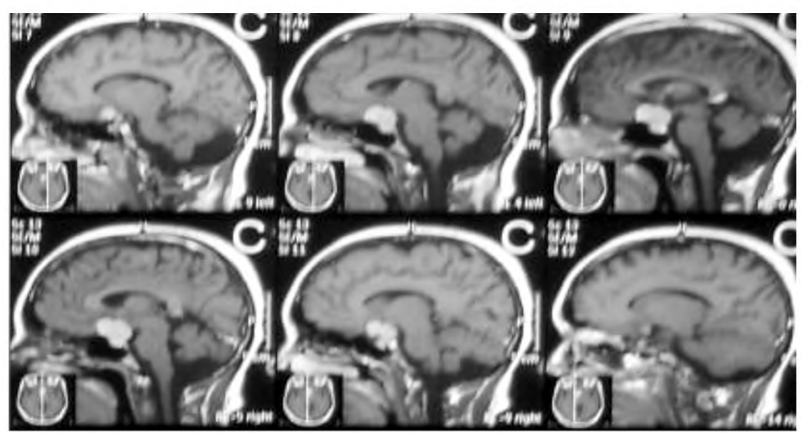

Image (5): Pre-operative MRI brain sagital cut show suprasellar meningioma.

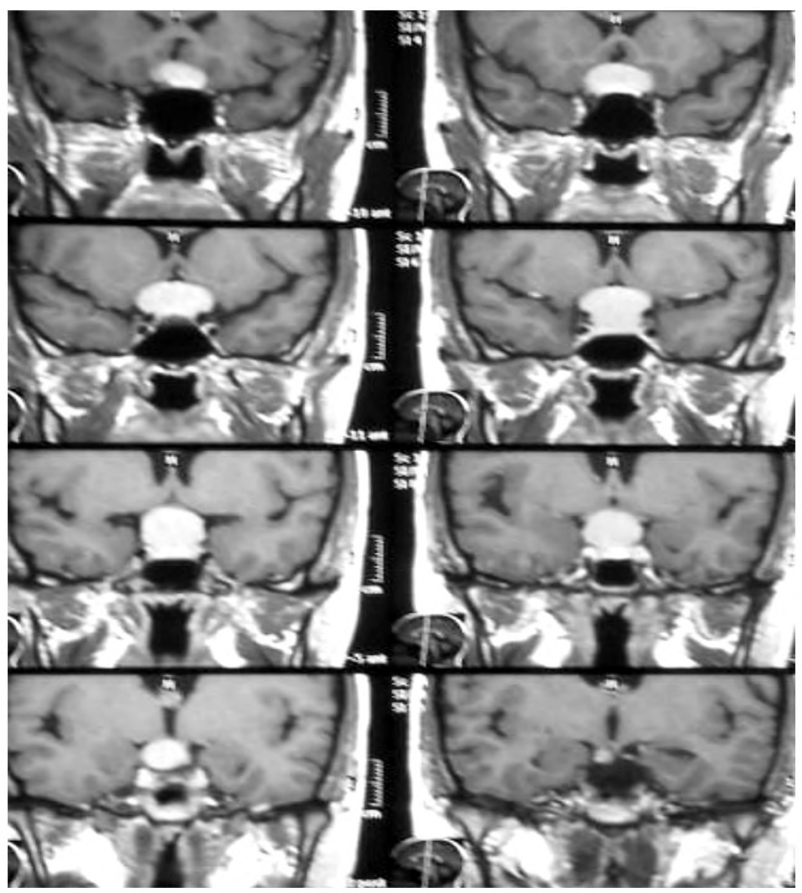

Image (6): Pre-operative MRI brain coronal cuts show suprasellar meningioma.

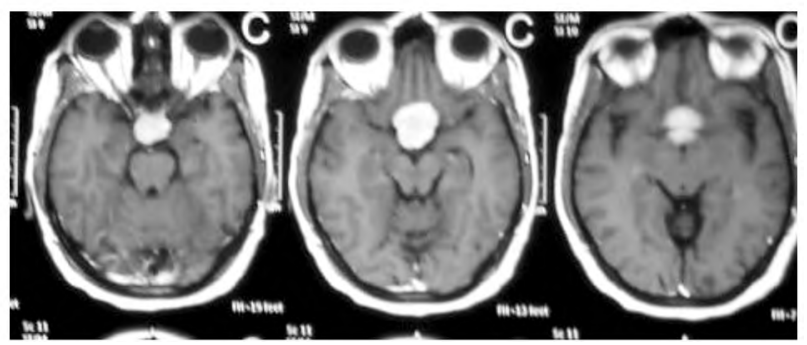

Image (7): Pre-operative MRI brain axil cuts show suprasellar meningioma.

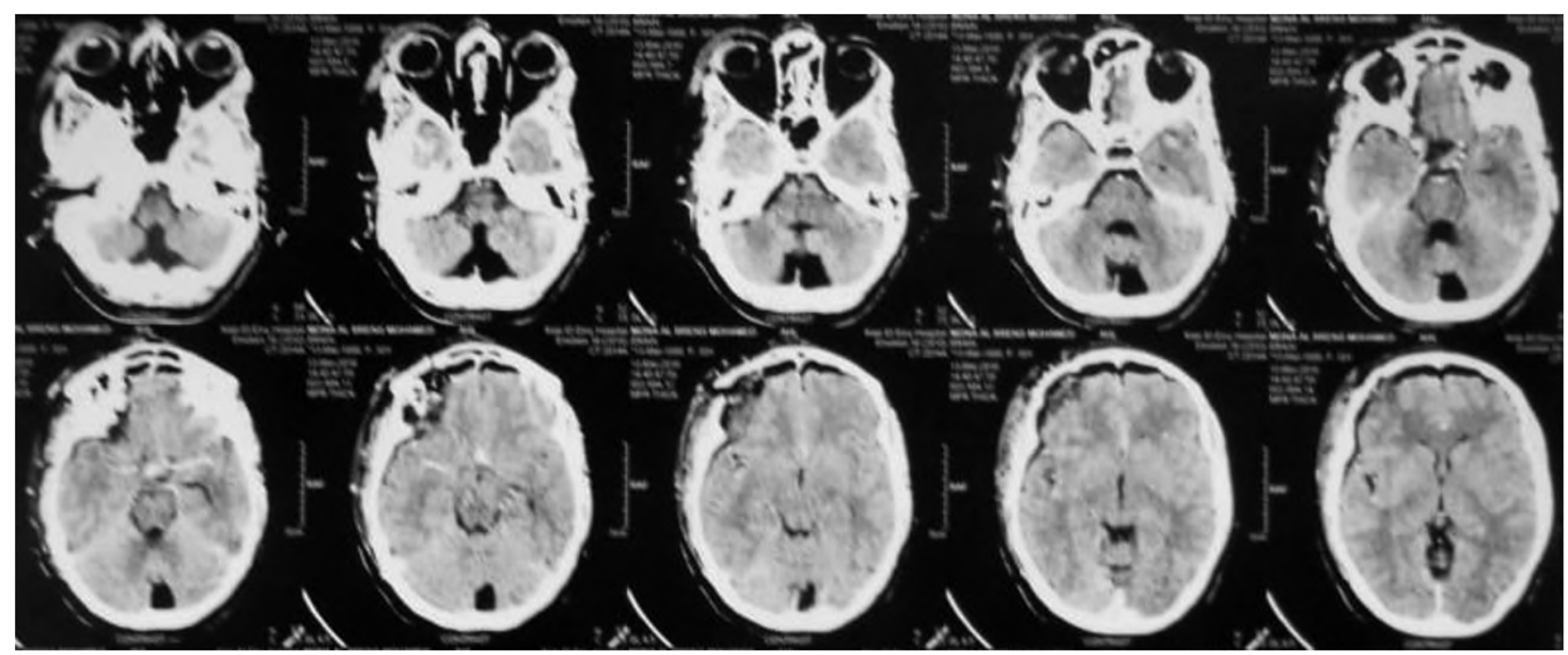

Image (8): Post-operative CT brain axil cuts show total removal of suprasellar meningioma thorough LSO approach. 


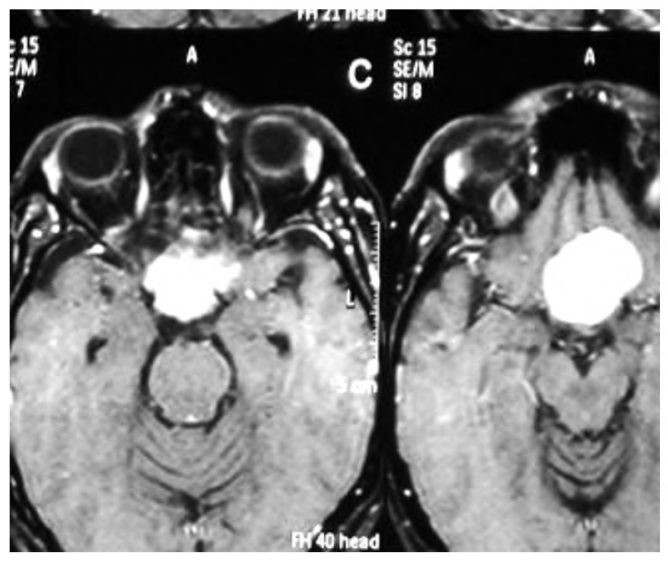

Image (9): Pre-operative MRI brain axil cuts show suprasellar meningioma.

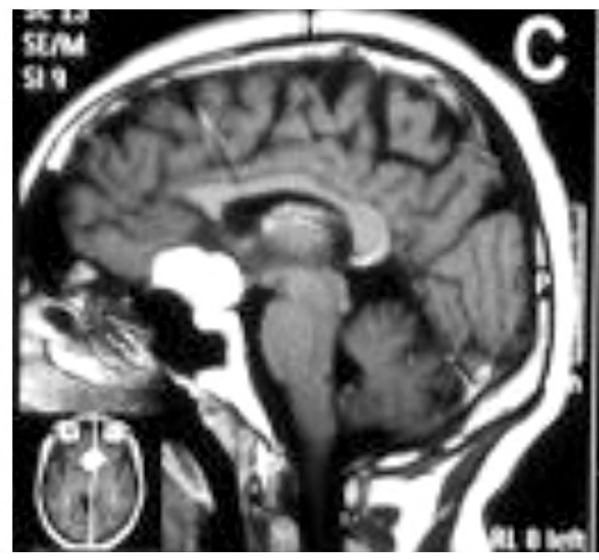

Image (10): Pre-operative MRI brain sagital cut show suprasellar meningioma.
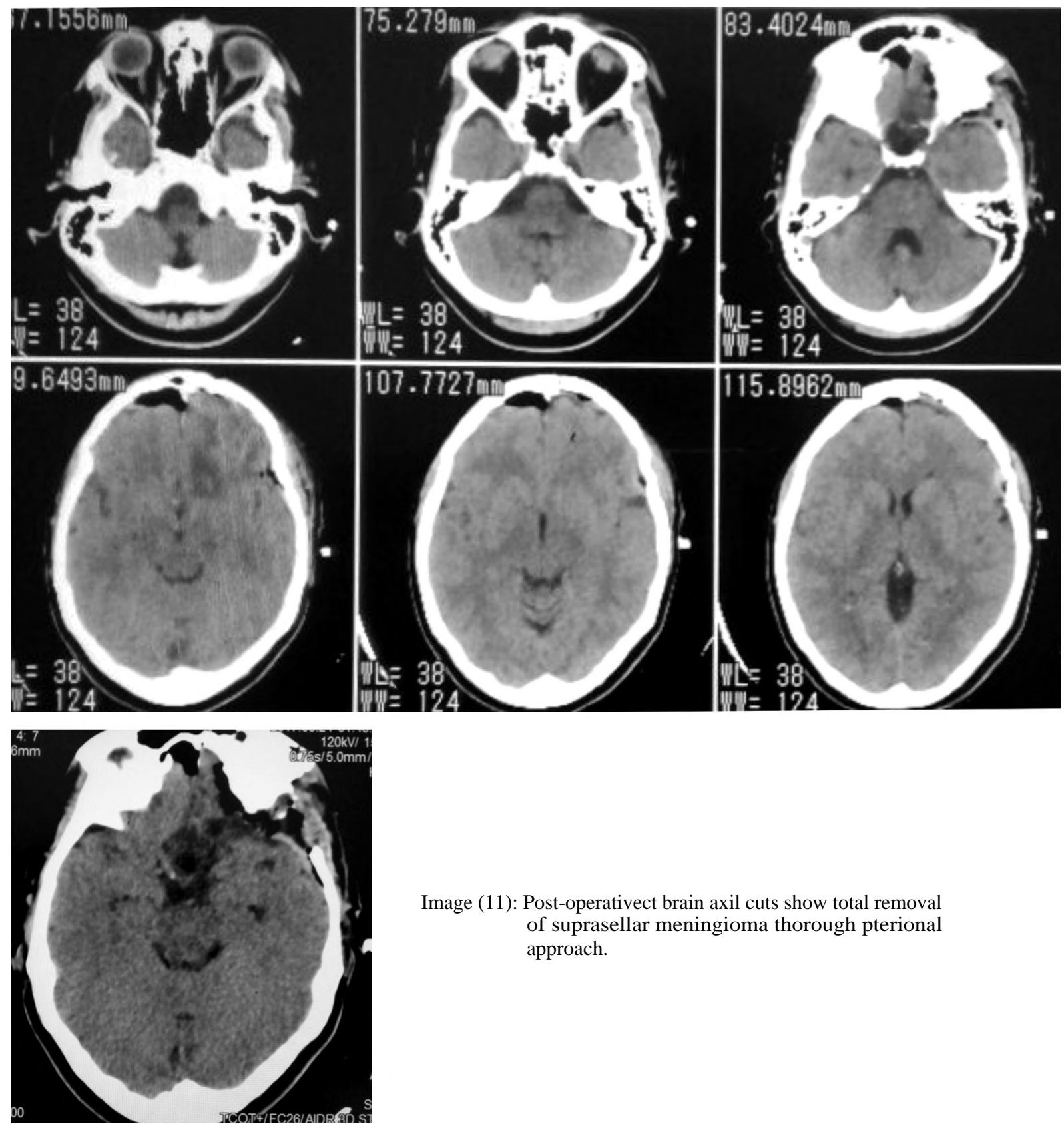

Image (11): Post-operativect brain axil cuts show total removal of suprasellar meningioma thorough pterional approach. 


\section{Discussion}

The LSO approach led to similar surgical results of more extensive procedures, such as pterional Approach.

Through reviewing the literature, it appears that the pterional approach is the most stander approach in the surgical management of suprasellar meningioma Dandy in 1938 was the first one describe these approaches and later become modify and become perfected by Yasargil, who reported that all suprasellar meningioma could be treated via a pterional route $[\mathbf{1 , 2 , 8 ]}$.

Although it is used to utilize the pterional approach to address many intracranial lesions, the classic pterional approach has been re-evaluated recently and compared with other approaches such as the lateral supraorbital approach $[3,5]$.

In general, LSO approach has been developed to minimize manipulation with the temporalis Muscle and the bone of sphenoid wing as well as less cosmetic disfigurement due to the skin incision being hidden under hair of eyebrow $[6,7,10]$.

However many neurosurgical approaches need number of strikes to obtain a careful balance between reducing tissue trauma and provision of maximum anatomic exposure and safe surgery careful understanding of these modified surgical routes, of the anatomic areas to which they offer an excellent route, and of the operability associated with them is essential for realizing the limitations and advantages of these approaches [5,6,12]

Knowing the limitations of these procedures aids in determining the best indications for each approach, and using the advantageous of these approaches will help to deliver the treatment that is the most appropriate for each patient $[\mathbf{1 2 , 1 3 , 1 7 ]}$.

\section{Evolution of the supraorbital eyebrow approach:}

Approaches via the anterior skull base, medial temporal lobe, suprasellar and parasellar regions, and brainstem have evaluated significantly in the last three decades with the aim to minimal brain retraction and also maximum visualization $[14,15,20]$

The LSO has been modified considerably with advancements in neuroanesthesia and the microsurgery techniques, the keyhole concept became standard approaches. Although the craniotomy is smaller, the access is the same. The small size of the supraorbital craniotomy provides an exposure giving access to the anterolateral subfrontal working space that has been effective.
With meticulous tissue handling and surgical techniques, a skin incision through the eyebrow can be used to perform a supraorbital craniotomy, and thus minute tissue trauma and small surgical time [20-23].

\section{Appropriately and effectivity of the approach:}

It is must consider in each case based on individual criteria as the imaging characteristics of each case and individual anatomical variation support whether a lesion is treated through a particular approach. And may depend on the Surgeon's familiarity to each the approaches.

However, the surgeon must recognize the anatomical limitations of the approach. Gross total excision was (75\%) group A, while it $(72.6 \%)$ group B almost same result in both approaches without significant deference [11,13,17] .

\section{Surgical exposure and accessibility:}

By understanding the anatomic exposure given to surgical approach may augment the decision making during the choice of a specific approach.

It must know there are many factors need to asses the operability and sefty [2,5,9] some of which, as:

- Skill of surgeon and orientation of anatomy and limitation of the approach.

- Deferent pathology.

- Tumour extension.

- Advanced neuroanesthesia.

- Advanced microsurgical technique.

The LSO approach offers similar access to optic nerves, optic chiasm, and sellar area our result same to result obtained by Figueiredo et al., [10-12].

In which compared the exposure given by pterional and lateral supraorbital approaches in which found no difference in the area of exposure in both approaches.

\section{Cosmesis:}

Good cosmetic outcome achieved with a skin incision through the eyebrow placing the incision at the upper edge of the eyebrow and with meticulous tissue handling and closure, the incision line, and scar are practically undetectable three months post-operatively $[6,7,9,10]$.

There is no bone defect at the pterion, abnormal growth of bone was observed. However, a minimal bone defect on the forehead in sit of the craniotomy 
cut was found. Because the LSO approach uses a small skin incision and involves minimal temporalis muscle dissection, the pain of the scalp, temporalis muscular atrophy, and difficulty of mastication rarely occurred [2-5]

\section{Limitations of this study:}

A small number of cases in these study over four years and also there was an incomplete followup from the patient because of the reluctance of patient for a cosmetic outcome, recurrence and outcome of surgery, so these studies need multicenter, more time to collect a large number of case.

Also, we used the pterional approach to remove suprasellar meningioma in eleven patient in our study and result was good the LSO approach was done in nine patient led to similar surgical results as pterional approaches so the extension of the craniotomy via pterional approach to expose the middle cranial fossa was not necessary when treating suprasellarmenimgioma.

\section{Conclusion:}

LSO approach is safe, less invasive and provides same accessibility to suprasellarmeningiomas as compared to classic pterional approach.

\section{References}

1- AL-MEFTY O. and FOX J.L.: Superolateral orbital exposure and reconstruction. Surg. Neurol., 23: 609-13, 1985.

2- YASARGIL M.G. and FOX J.L.: The microsurgical approach to intracranial aneurysms. Surg. Neurol., 3: 7145,1975 .

3- CAVALANTI D.D., GARCIA-GONAL E.Z. and SPETZLER R.F.: Quantitative anatomic study of the transciliary supraorbital approach: Benefits of additional orbital osteotomy? Neurosurgery 66 (6 Suppl. Operative): 205$10,2010$.

4- CHALOUHI N., JABBOUR P., IBRAHIM I., STARKE R.M. and YOUNES P.: Surgical treatment of ruptured anterior circulation aneurysms: Comparison of pterional and supraorbital keyhole approaches. Neurosurgery, 72: 437-42, 2013

5- CHENG C.M., NOGUCHI A., DOGA N. and MENOMEY S.O.: Quantitative verification of the keyhole concept: A comparison of area of exposure in the parasellar region via supraorbital keyhole, frontotemporalpterional, and supraorbital approaches. Laboratory investigation. J. Neurosurg., 118: 264-9, 2013.

6- CZIRJAK S. and SZEIFERT G.T.: Surgical experience with frontolateral keyhole craniotomy through a superciliary skin incision. Neurosurgery, 48: 145-50, 2001.

7- DARE A.O., LANDI M.K. and GRAND W.: Eyebrow incision for combined orbital osteotomy and supraorbital minicraniotomy: Application to aneurysms of the anterior circulation. Technical note. J. Neurosurg., 95: 714-8, 2001.
8- DELASHAW J.B. J.R., JANE J.A. and KASSELL N.F.: Suprao rbital craniotomy by fracture of the anterior orbital roof. Technical note. J. Neurosurg., 79: 615-8, 1993.

9- FATEMI N., DUSICK J.R., De PAIVA NETO M.A. and KELLY D.F.: Endonasal versus supraorbital keyhole removal of craniopharyngiomas and tuberculumsellaemeningiomas. Neurosurgery, 64 (5 Suppl 2): 269-86, 2009.

10- FIGUEIREDO E.G., DESHMUKH P. and NAKAJI P.: The minipterional craniotomy: Technical description and anatomic assessment. Neurosurgery, 61: 256-64, 2007.

11- FIGUEIREDO E.G., DESHMUKH P. and SPETZLER R.F.: The minipterional craniotomy: Technical description and anatomic assessment. Neurosurgery, 61 (5 Suppl 2): 256-65, 2007.

12- FIGUEIREDO E.G., DESHMUKH P. and SPETZLER R.F.: An anatomical evaluation of the mini-supraorbital approach and comparison with standard craniotomies. Neurosurgery, 59 (4 Suppl 2): ONS212-ONS220, 2006.

13- FRIES G. and PERNECKY A.: Endoscope-assisted brain surgery: Part 2-analysis of 380 procedures. Neurosurgery, 42: 226-32, 1998.

14- HAYHURST C. and TEO C.: Tuberculumsella meningioma. Otolaryngol. Clin. North Am., 44: 953-63, viii-ix, 2011.

15- HERNESNIEMI J., ISHII K. and NIEMELA M.: Lateral supraorbital approach as an alternative to the classical pterional approach. Acta. Neurochir. Suppl., 94: 17-21, 2005.

16- JALLO G. and BOGNAR L.L.: Eyebrow surgery: The supraciliary craniotomy: Technical note. Neurosurgery 59 (1 Suppl 1): ONSE157-ONSE158, 2006.

17- JALLO GI SUK I. and BOGNAR L.: A superciliary approach for anterior cranial fossa lesions in children. Technical note. J. Neurosurg., 103 (1 Suppl): 88-93, 2005.

18- JANE J.A., PARK T.S., POBERESKI N., WINN H.R. and BUTLER A.B.: The supraorbital approach: Technical note. Neurosurgery, 11: 537-42, 1982.

19- JHO H.D.: Orbital roof craniotomy via an eyebrow incision: A simplified anterior skull base approach. Minim. Invasive Neurosurg., 40: 91-7, 1997.

20- KANAAN I.N.: Trans-eyebrow mini-orbitozygomaticpterional approach for minimally invasive skull base surgery. Minim. Invasive Neurosurg., 48: 34-8, 2005.

21- LITTLE ASGP, DARBAR A. and TEO C.: Supraorbital eyebrow approach: A less invasive corridor to lesions of the anterior cranial fossa, parasellar region, and ventral brainstem, and Skull Base Surgery. Milan: Springer-Verlag 27-38, 2010.

22- MAUS M. and GOLDMAN H.W.: Removal of orbital apex hemangioma using new transorbital craniotomy through suprabrow approach. Ophthal. Plast. Reconstr. Surg., 15: 166-70, 1999.

23- PARK J., KANG D.H. and CHUN B.Y.: Superciliary keyhole surgery forunruptured posterior communicating artery aneurysms with oculomotor nerve palsy: Maximizing symptomatic resolution and minimizing surgical invasiveness. Clinical article. J. Neurosurg., 115: 700-6, 2011 


\section{النهج الجانبى فوق الحاجب مقابل نهج التريونى الكلاسيكى التوفي

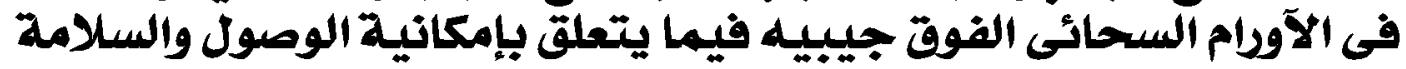

خلفية: نهج الجانبى فوق الحاجب هوتعديل للنهج الكلاسيكى لتريونى I مع مزايا شق الجلد القصير وقص العظم حجمى صغيرة بالمقارنة مع نهج التريونى.

الهدف من الدراسةة: نصن نهدف إلى تقديم تجريتنا الجراحية فى المقارنة بين النهج الجانبى فوق الحاجب والنهج الكلاسيكى التريونى

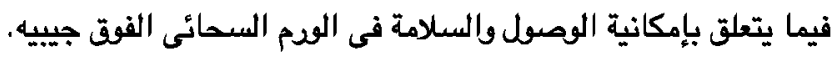

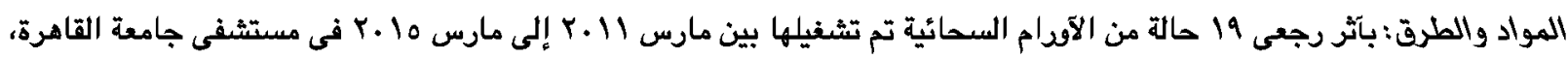

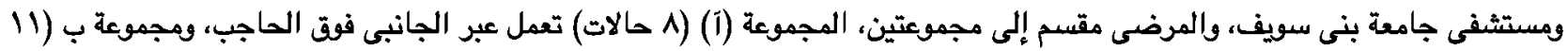

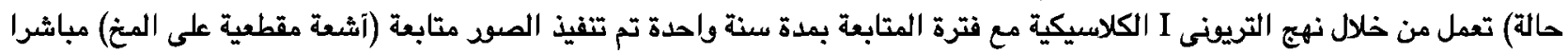

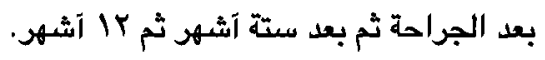

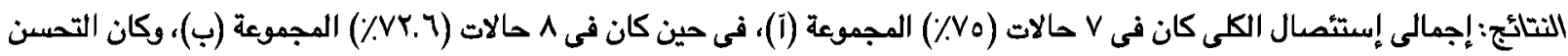

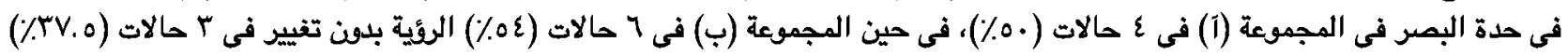

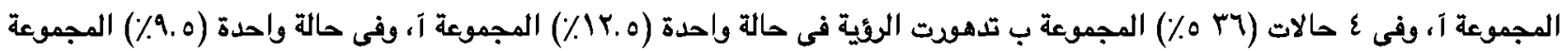

كان مرض السكرى الكاذب العابر فى حالة واحدة (ه .9٪) المجموعة ب ولا توجد حالات فى الججموعة آ. الخلاصة: نهج الجانبى فوق الحاجب هو آمن، وآقل غزو وتوفر نفس إمكانية الوصول إلى الآقدام السحائية الفوق جييية بالمقارنة مع نهج التريونى الكلاسيكى. 